\author{
Daniel Puciato \\ https://orcid.org/0000-0002-2390-6038 \\ Opole University of Technology \\ Faculty of Physical Education and Physiotherapy \\ Department of Tourism and Recreation \\ d.puciato@po.edu.pl
}

\title{
BEHAVIORAL FACTORS IN HOTEL LOCATION: A STUDY OF HOTELS FROM OPOLE PROVINCE IN POLAND
}

\begin{abstract}
The choice of location is one of the key economic decisions for hotel owners. In modern economics traditional premises are increasingly questioned, and assumptions are often made involving imperfect competition, limited rationality of behavior, and the incomplete scope of information or the inability to use it effectively. This is also reflected in the theory of location within which a behavioral trend has been developed assuming the occurrence of non-economic, subjective factors in making location decisions. The aim of the paper is to identify behavioral factors in hotel location in Opolskie Province in Poland. The paper uses four main research methods: literature review, documentation, diagnostic survey and individual case studies. The study results confirm the importance of the behavioral approach in the process of selecting a location for independent hotels in Opolskie Province, involving the choice of secondary or primary locations. In the latter case, the decision-making process is based entirely on behavioral factors or is supplemented by them in situations where an objective approach is not connected with decision-making certainty. Behavioral factors such as intuition, emulation, experience, place of origin and residence, individual cases and the influence of others should be regarded as highly significant.
\end{abstract}

Keywords: location, hotels, behavioral factors, Opole Province.

\section{INTRODUCTION}

One of the key economic decisions made by hotel proprietors is the choice of hotel location. A good location and an appropriately adjusted service program determine, in principle, the hotel's profitability and development prospects. Location is important not only for hoteliers, i.e. owners, managers and employees, but also for hotel guests - tourists, business representatives, and even for contracting partners - travel agencies, suppliers, as well as competitors and other hotel facilities (Cheng, 2018; Ju, Zhang, Wang, 2018; Popovic, Stanujkic, Brzakovic, Karabasevic, 2019; Ren, Qiu, Ma, Lin, 2018). The term "business location" means "the location of the size and type of a business, facility, or a set of facilities, within a defined area" (Budner, 2004, p. 22). A distinction between general and specific locations can be made. A general location consists of choosing a specific country, region and settlement unit (municipality, community) in which a given hotel facility could be located. Specific location is connected with choosing a specific place (land plot) where a given facility can be built. Within the conceptual category of hotel location, primary (active) and secondary (passive) locations can also be distinguished. Primary location is the selection of a new place of business for a start-up company or facility, e.g. construction of a new hotel. Secondary location, on the other hand, concerns a change in purpose of existing facilities or their extension, modernization or reconstruction (Budner, 2004; Godlewska, 2005).

Most location theories are based on several assumptions e.g. excellent competition, full rationality, access to information and the search for optimal locations by companies. In the process of selecting locations for business activities, decisions are based on an analysis of location factors, which Godlewska (2005, p. 35) define as "Specific features of particular locations, which have a direct impact on the formation of investment expenditure during the construction of the company's facility(ies) as well as on the net profitability of the business activity carried out in those locations". The results of previous studies indicate that location factors are important for hotels, and can be contractually aggregated into three groups: factors 
minimizing costs, which include construction factors (mainly land and labor) and all the related costs; factors maximizing revenues including demand and supply volume; and stimulating factors including administrative, planning, and financial incentives from public authorities (Chou, Hsu, Chen, 2008; Damborsky, Wokoun, 2010; Kowalczyk, 2001; Kundu, Contractor, 1999; Leśniewska-Napierała, Napierała, 2017; Matczak, 2017; Puciato, 2016; Włodarczyk, 2017; Yang, Wong, Wang, 2012; Zhank, Guillet, Gao, 2012; Żakowska, Podhorodecka, 2018). However, economic practice shows that the process of location choice also contains significant uncertainties and risks which should be treated as types of corporate costs.

Modern economic theory, however, largely undermines the traditional assumptions (Griffin, Tversky, 1992). Imperfect competition, a limited rationale for given behaviors, incomplete information or the inability to use it effectively, are currently presumed. They are also reflected in the theory of location which includes a behavioral trend based on premises accounting for extra-economic, subjective determinants of location decision making (Kuciński, 2009). Within this concept the main emphasis is not on searching for methods of optimizing the choice of location, but on understanding the mechanism of decision making. The selection process should be based on the indication of a satisfactory location, not an optimal one. Location decisions are long-term in nature and the assessment of individual locations may change over time, e.g. as a result of emigration of employees or changes in the level of tourist interest in specific reception areas. Under such circumstances, the aspiration to optimize the location decision loses its meaning. Making satisfactory, but not necessarily optimal choices, and using simplified heuristics in the decision-making process are key elements of the theoretical perspective of behavioral economics (Kahneman, 2011). The use of a behavioral approach in the process of making location decisions occurs especially when there is too much information to be processed, there are elements of uncertainty, and the time for making decisions is limited.

So far, empirical studies on the behavioral aspects of the process of location choice have only addressed industrial companies and indicated the significance of the previous experience of foreign investors (Mariotti, Mutinelli, Piscitello, 2008; Townroe, 2007). However, there is a lack of research on tourism market entities including hotels. Our earlier research indicates, however, that a behavioral perspective may be important, especially in relation to the location decisions of small independent hotels of low or medium standard, financed from Polish capital (Puciato, Dziedzic, 2017; Puciato, Gawlik, Goranczewski, 2016; Puciato et al., 2017; Puciato et al., 2019).
In the context of these observations, the present study attempts to identify the behavioral factors associated with hotel location decisions in Opolskie Province in Poland.

\section{BEHAVIORAL ASPECTS OF THE PROCESS OF HOTEL LOCATION CHOICE}

The development of hotel location theory has until now been based mainly on traditional concepts and has proceeded in two directions. In the former, hotels are considered part of the tourism economy, and location theories have been applied to tourism as a whole. Theories in this category include Christaller's notion of peripheries (1964), Butler's tourism area life cycle (1980), and Miossec's tourism space perception (1977). In the latter, hotels are treated as separate economic entities with certain specific features, which has been reflected, among others, in the concepts of the hotel market development cycle (Hotelling, 1929) and hotel sector internationalization (Alexander, Lockwood, 1996). The main location factors within these theories are presented in Table 1.

In their empirical studies both Polish and foreign authors tackled the problem of hotel location factors. For example, Kowalczyk (2001) considered the most convenient hotel locations in cities to be routes and hubs, city centers, shopping and business centers, trade fairs, river banks, and the vicinity of major tourist attractions. The most advantageous locations for hotels outside the city are main transport routes, suburbs of large cities, as well as recreation, exhibition and trade fair areas. Puciato \& Dziedzic (2017) showed that the most important factors for locating independent hotels included access to qualified staff and investment sites, the supply of tourism services, intensification of competition in the tourism sector, and planning and administrative incentives from public authorities. According to Yang, Wong \& Wang (2012) the most important business hotel location factors are accessibility for business tourists, demand volume, agglomeration effect, accessibility of public services and social goods, and urbanization. Ussi \& Wei (2011), on the other hand, in their research on the significance of particular hotel location factors showed that the most important from the investor's point of view are level of regional tourism market development, availability of diverse tourism assets, physical infrastructure and public services, economic growth, political stability and openness to tourists.

However, there have been few empirical studies examining non-economic factors for hotel location. Romero-Martinez, Garcia-Muina, Chidlow \& Larimo 
Table 1. Behavioral factors of location

\begin{tabular}{|c|c|}
\hline Theories of location & Main location factors \\
\hline Peripheries & - natural tourism assets. \\
\hline Tourism area life cycle & $\begin{array}{l}\text { - tourism demand volume; } \\
\text { - tourism supply (tourist facilities); } \\
\text { - tourism assets (natural and cultural); } \\
\text { - innovativeness of the tourism area. }\end{array}$ \\
\hline Tourism space perception & $\begin{array}{l}\text { - tourism demand (tourist flows, tourist preferences); } \\
\text { - local demand (population size and structure); } \\
\text { - supply of tourist, cultural, and entertainment services; } \\
\text { - agglomeration effect; } \\
\text { - organization of major events; } \\
\text { - tourism market (employment); } \\
\text { - tourism assets; } \\
\text { - environmental characteristics; } \\
\text { - communication accessibility; } \\
\text { - labor market (flexibility); } \\
\text { - local tourism policy. }\end{array}$ \\
\hline Hotel market development cycle & $\begin{array}{l}\text { - national and regional level of economic development (macroeconomic indices); } \\
\text { - economic condition of existing hotels (microeconomic indices); } \\
\text { - fluctuation of macro- and microeconomic indices (course and range of fluctuations). }\end{array}$ \\
\hline Hotel sector internationalization & $\begin{array}{l}\text { - globalization; } \\
\text { - internationalization of the economy; } \\
\text { - economic development level; } \\
\text { - profitability level of the hotel industry; } \\
\text { - technological development; } \\
\text { - tourism demand; } \\
\text { - tourism supply. }\end{array}$ \\
\hline
\end{tabular}

Sources: author on the basis of Alexander, Lockwood (1996); Butler (1980); Christaller (1964); Hotelling (1929); Miossec (1977).

(2019) showed that in the case of hotel chains, cultural differences, linguistic differences and formal institutional factors may be important location determinants. Albert \& Rechnitzer (2018), on the other hand, stated in their study that not all the reasons for choosing a location are objective as sometimes the opening of a hotel is a spontaneous decision. It is therefore fully legitimate and desirable to consider behavioral factors in the process of hotel location choice.

The basic principles (assumptions) of the behavioral approach to the process of hotel location choice are:

1. The choice of a hotel site is not always a fully intentional process for a potential entrepreneur.

2. Starting a hotel may involve a choice of both primary and secondary locations.

3. The process of hotel location choice is characterized by a high level of uncertainty and risk.

4. Potential investors do not have access to full information and are not always able to use it effectively.

5 . Investors are characterized by limited rationality in their location decisions and sometimes follow subjective premises including intuition.

6. The location decision is usually based on the analysis of factors that minimize costs, maximize profits, and stimulation; and is made in conditions of uncertainty involving behavioral factors.
7. In some situations, investors may base their location decisions only on behavioral factors.

8. The lack of an optimal location is not a reason for investors to change their investment plans.

9. Investors in the MSME sector, who are interested in building an independent hotel, sometimes choose a merely satisfactory location, due to high transaction costs and relatively low bargaining power (Puciato, 2015).

As already mentioned, four groups of location factors can be distinguished: minimizing costs, maximizing revenues, stimulation and behavioral factors. This division is, of course, a simplification, as certain factors can be included in more than one group. The proposed groups of determinants seem to be appropriate as hotels wishing to maximize their profit may undertake actions mainly aimed at minimizing costs or maximizing revenues. The location of a hotel is of great importance for the development of both these financial categories, and in terms of costs it concerns not only the use of the hotel facilities but also their design and construction.

Behavioral factors are the most important group of location determinants in terms of the research goals. Some investors rely entirely on them in their location decisions. On the other hand, investors who take into account objective criteria for location choice may also 
sometimes consider behavioral factors. This happens particularly in the case of decision uncertainty when an investor who chooses a hotel location from several previously selected sites with a similar "location value" may tend to consider subjective premises. These may include such location factors as the intuition and experience of the decision-maker, his or her place of origin and residence, and the 'bandwagon effect' (Puciato, 2015). Incidentally, it should also be noted that the last of these factors may also have an objective basis. It is connected with the process of development of the tourism function in reception areas and is sometimes visible in the initial phase of investment inflow to a specific location, when a successful investor finds his followers. This often leads to a spatial concentration of investments, which may bring certain economic benefits for the companies located there, especially with regard to the effect of agglomeration or the availability of public goods. These benefits may be related, for example, to a high level of spatial concentration of business entities of a specific profile, or to the joint use of a specific infrastructure network (transport, gas and energy, water and sewage). In extreme cases, the 'bandwagon effect' may also be a kind of a nascent effect leading to the creation of complex cluster structures.

Table 2 presents behavioral location factors in the context of investors' cognitive and motivational biases. Each of the factors can be applied to specific effects and heuristics (Kahneman, 2011; Thaler, Sunstein, 2017; Zielonka, 2011) according to the principles of behavioral economics. Choosing a hotel location by using intuition may be connected with such cognitive tendencies as excessive optimism and the affect heuristic. In the former, the decision-maker may be overconfident in his or her intuition and be unrealistically convinced of a good choice of hotel location. The decision may also be influenced by a noticeable emotional state of the decision-maker (the affect heuristic), which becomes an indicator of a too optimistic or too pessimistic assessment of a potential location. One, but not necessarily the key, characteristic may in this case determine the assessment and then selection or rejection of the site. Affective priming and the 'trap of projection' are, in turn, potential motivational biases of entrepreneurs using their intuition. Emotional decision making may involve the decision-maker's attachment to information that supports his or her emotional state while ignoring information that is contrary to it. A satisfied decision-maker will appreciate information about a given place more optimistically, and a dissatisfied decision-maker will appreciate it more pessimistically. Affective priming can lead to the strengthening of good or bad moods, to maintaining the status quo or to an analysis of problems and consideration of possible changes. A decision based on intuition and mood may lead to falling into the 'trap of projection', generating an expectation that the current emotional state, followed by the assessment of a given hotel's location, will remain unchanged in the future.

People who rely on their own experience in the process of making location decisions are exposed to excessive confidence in their own knowledge and skills. Their belief in the correctness of their own assessments, and overestimation of their competences, may sometimes lead to a wrong decision. This phenomenon is often accompanied by the illusion of control, i.e. hotel owner's conviction that it is possible to influence the course of phenomena that are actually independent (e.g. tourism demand volume or access to labor). Using experience is also connected with the accessibility heuristic. The easier the access in memory to previously made business or even non-business decisions the decision-maker has, the more likely he or she is convinced of their importance and of the occurrence of a similar situation (e.g. favorable macroeconomic conditions) in the future. People are more sensitive to losses than to profits (loss aversion), which means that even in the case of temporary financial difficulties, decision-makers,

Table 2. Behavioral hotel location factors and investors' cognitive biases and motivational biases

\begin{tabular}{|l|l|l|}
\hline \multicolumn{1}{|c|}{ Behavioral factors } & \multicolumn{1}{|c|}{ Cognitive biases } & \multicolumn{1}{c|}{ Motivational biases } \\
\hline Intuition & $\begin{array}{l}\text { - excessive optimism, } \\
\text { - affect heuristic. }\end{array}$ & $\begin{array}{l}\text { - affective priming, } \\
\text { - trap of projection. }\end{array}$ \\
\hline Experience & $\begin{array}{l}\text { - overconfidence in one's knowledge and skills, } \\
\text {-illusion of control, } \\
\text { - accessibility heuristic }\end{array}$ & $\begin{array}{l}\text { - loss aversion, } \\
\text { - hedonic treadmill. }\end{array}$ \\
\hline Place of origin and residence & $\begin{array}{l}\text { - hindsight bias, } \\
\text { - cognitive dissonance. }\end{array}$ & $\begin{array}{l}\text { - mere ownership effect, } \\
\text { - status quo bias. }\end{array}$ \\
\hline Bandwagon effect & $\begin{array}{l}\text { - confirmation bias, } \\
\text { - anchoring effect, } \\
\text {-fundamental attribution error, } \\
\text { - representativeness heuristic, } \\
\text { - positive and negative recency effect. }\end{array}$ & $\begin{array}{l}\text { - mental accounting, } \\
\text { - sunk costs, } \\
\text { - hedonic framing, } \\
\text {-disposition effect, } \\
\text { - myopic loss aversion. }\end{array}$ \\
\hline
\end{tabular}

Source: author on the basis of Kahneman (2011); Thaler, Sunstein (2017); Zielonka (2011). 
who base their choice of location on experience, may opt out of a location with high potential which, however, has not been yet very popular among other entrepreneurs. On the other hand, those who have recently been successful may get stuck on the so-called hedonic treadmill and choose even a risky location only to meet growing financial expectations to maintain the current level of life satisfaction.

The effects of hindsight bias and cognitive dissonance are likely to impact decision-makers for whom the key location factor is the place of origin or residence. This involves convincing the decision-maker that events could have been predicted and that they were much more likely and easier to predict than nonexistent events. Cognitive dissonance, i.e. a feeling of tension due to a conflict between cognitive elements, may also occur. It can intensify as a result of the increased significance of one element (e.g. choice of location of a new facility for the financial situation of the entire hotel chain), the degree of contradiction between elements (e.g. choice of location based on the place of origin and not on the market situation in this area), or of the inability to reconcile elements (e.g. threat of financial losses in a hotel in the chosen location). The choice of location based on one's own place of origin or residence strengthens the effect of mere ownership as the decision-makers value goods they own and/or know more than those they do not own and/or know. This may lead to the 'status quo bias', i.e. maintaining the choice of location in the place of residence or origin due to aversion to potential losses.

The 'bandwagon effect' as a potential factor of hotel location involves the greatest number of threats resulting from the decision-maker's bias. The decision-maker may search for or interpret incoming information in such a way as to obtain confirmation for the hotel's chosen location (confirmation bias). This may involve the 'anchoring effect', where an individual depends too heavily on an initial piece of information offered. Making location decisions based on the behavior of other people is sometimes combined with a tendency to overestimate personality factors and underestimate situational factors in explaining their behavior ('fundamental attribution error'). Such a choice is also often made on the merits of individual cases, rather than on larger representative samples of people making such decisions in the past. It can also be expected that the most important decisions for decision-makers will be those made recently and their forecast of maintaining or reversing trends in the financial situation of hotels al ready operating in this area. The investments already made by investors in choosing a particular hotel location (e.g. time and effort spent, travel costs, administrative fees, purchase of reports, etc.) may lead to the phenomena of mental accounting and sunk costs. The difficulty or inability to recover these expenditures may affect the continuation of the process of location selection.
The greater the resources invested by decision-makers from their perspective, the greater their reluctance to give up even a highly risky project. Depending on the situation, these expenditures can also be accumulated or divided (hedonic framing). The 'disposition effect' may also occur, in which case the decision-maker, being aware of the high risk of failure of the future hotel in a given location, will not be willing to withdraw from a particular investment. Decision-makers using the 'bandwagon effect' may also feel uncomfortable once they make a preliminary location decision and observe the temporary problems of other hotels in that location (myopic loss aversion).

\section{METHODS}

Four main research methods were used in the research: literature survey, documentation, diagnostic survey and individual case studies. The literature survey included an inventory of books and articles on the behavioral aspects of hotel location. The use of the documentation method (indirect observation) was connected with the acquisition of data from secondary sources, Statistics Poland (2019) and the Polish Ministry of Sport and Tourism (2019), which were necessary to identify hotels located in the Opolskie Province. As part of the diagnostic survey open structured in-depth interviews were conducted. The research tool was the author's interview questionnaire consisting of seven open questions regarding selected aspects of hotel location, as well as a respondent's details section. During the interview respondents were asked the following questions: 1. Was your process of selecting the hotel location a decision based on objective premises?

2. Was the current location of the hotel the only one taken into account?

3. Did you have any previous experience in selecting hotels or other types of business?

4. What were the most important factors for you when choosing the hotel location?

5. Did your location decision result from any stimulating activities undertaken by local or regional authorities?

6. What kind of behavioral factors did you consider in the process of hotel location selection?

7. How did you collect information before selecting the location?

Before the study the questionnaire was subjected to pilot tests and detected errors were corrected. During the direct research procedure consisting of collecting data from primary sources, respondents were informed beforehand about the purpose and course of the research. The selection of the sample was purposive, and the survey included 31 hotels whose owners expressed their 
Table 3. Organizational and functional characteristics of the hotel enterprises studied

\begin{tabular}{|c|c|c|c|}
\hline Criterion & Type & Number & Percent \\
\hline \multirow{3}{*}{ Origin of capital } & Polish & 22 & 71,0 \\
\hline & foreign & 1 & 3,2 \\
\hline & mixed & 8 & 25,8 \\
\hline \multicolumn{2}{|l|}{ Total } & 31 & 100,0 \\
\hline \multirow{4}{*}{ Enterprise size } & micro & 0 & 0,0 \\
\hline & small & 19 & 61,3 \\
\hline & medium & 12 & 38,7 \\
\hline & large & 0 & 0,0 \\
\hline \multicolumn{2}{|l|}{ Total } & 31 & 100,0 \\
\hline \multirow{4}{*}{ Business and legal organization type } & individual owner & 15 & 48,4 \\
\hline & civil law company & 4 & 12,9 \\
\hline & general partnership & 4 & 12,9 \\
\hline & private limited company & 8 & 25,8 \\
\hline \multicolumn{2}{|l|}{ Total } & 31 & 100,0 \\
\hline \multirow{2}{*}{ Degree of integration } & independent & 29 & 93,5 \\
\hline & integrated & 2 & 6,5 \\
\hline \multicolumn{2}{|l|}{ Total } & 31 & 100,0 \\
\hline \multirow{5}{*}{ Hotel rating } & * & 2 & 6,5 \\
\hline & $* *$ & 6 & 19,4 \\
\hline & $* * *$ & 19 & 61,2 \\
\hline & $* * * *$ & 4 & 12,9 \\
\hline & $* * * * *$ & 0 & 0,0 \\
\hline \multicolumn{2}{|l|}{ Total } & 31 & 100,0 \\
\hline \multirow{4}{*}{ Main hotel product } & business & 17 & 54,6 \\
\hline & leisure/holiday & 10 & 32,3 \\
\hline & transit & 2 & 6,5 \\
\hline & conferences and conventions & 2 & 6,5 \\
\hline \multicolumn{2}{|l|}{ Total } & 31 & 100,0 \\
\hline
\end{tabular}

Source: author on the basis of survey results.

willingness to participate, i.e. about $48 \%$ of all hotel facilities in Opolskie Province. The main part of the research was conducted in the first half of 2019. The final method comprised individual case studies. The results of the survey led to the formulation of a collective 'case study' concerning the most typical situations regarding the behavioral location factors considered by decisionmakers. Among the hotels in the survey, $71.0 \%$ were financed by Polish capital, $25.8 \%$ with mixed capital and $3.2 \%$ with foreign capital. Small enterprises constituted $61.3 \%$ of all surveyed facilities, and medium enterprises $-38.7 \%$. Almost half (48.4\%) were enterprises with individual owners, and $51.6 \%$ were companies: $25.8 \%$ - private limited companies, $12.9 \%$ - civil law companies, and $12.9 \%$ - general partnerships. The examination of the degree of integration with other business entities showed that the majority $(93.50 \%)$ were independent, while only $6.5 \%$ were integrated hotels. Over $60 \%$ were categorized as three-star and almost $20 \%$ as two-star; four-star hotels were $12.9 \%$ and one-star $-6.5 \%$. The majority of hotels offered business (54.6\%) and leisure $(32.3 \%)$ services. On the other hand, transit hotels or conference or convention hotels amounted to $6.5 \%$ of the research sample respectively (Table 3).

\section{BEHAVIORAL FACTORS FOR HOTEL LOCATION SELECTION IN OPOLSKIE PROVINCE IN THE LIGHT OF EMPIRICAL RESEARCH}

The results show that the decision-makers in about half of the hotels $(48.4 \%)$ did not take any intentional actions based on objective premises aimed at choosing the location of their facilities. Moreover, one third of respondents $(32.2 \%)$ declared that although they had 
used objective methods for hotel location choice, they also took into account subjective factors. In almost every fifth hotel (19.4\%), including two integrated hotels, the choice of location was made on the basis of objective criteria (Fig. 1).

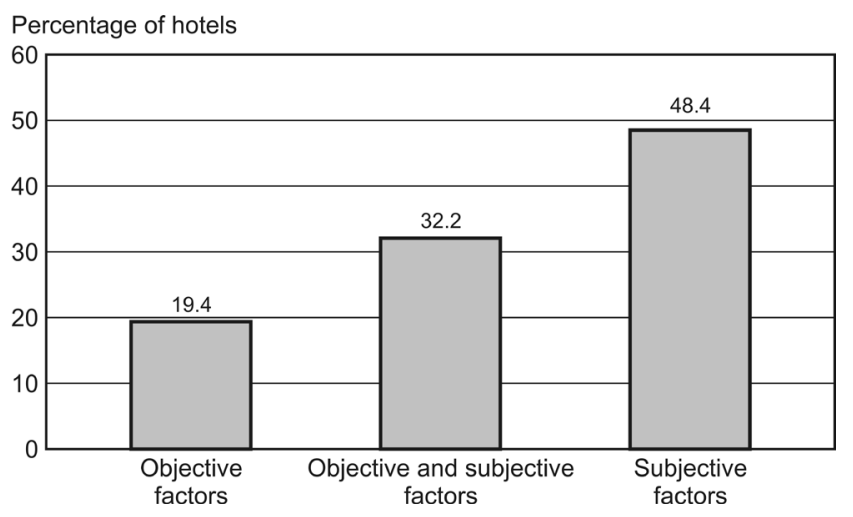

Figure 1. Factors of location for hotels in the Opolskie Province Source: author on the basis of survey results

Among the respondents taking a subjective approach to hotel location selection, three choice pathways can be distinguished:

- choice of secondary location;

- choice of primary location made solely on the basis of behavioral factors;

- choice of primary location made on the basis of objective location factors, supplemented with behavioral factors.

A common feature of hotels in the first two pathways was that their current location proved to be the only one considered by decision-makers, who in addition did not make use of any information concerning the hotel site.

In the case of secondary locations, where $36 \%$ of the surveyed owners opted for a subjective approach, the choice of secondary location was often linked to the expansion of an existing restaurant where several rooms were rented and to its transformation into a hotel. Some hotels were also developed as a result of changes in the nature of the business activity. As a result, hotel facilities were opened in the building where office premises or apartments were previously rented and where financial services, including insurance, were provided. In one case the hotel owners had previously operated a guest house which was thoroughly modernized and adapted to statutory requirements. In one case the owners owned two historic buildings in the city center and after appropriate adaptation started to provide hotel services in them.

In several cases respondents had previously owned undeveloped property (land plots) on which they later built hotels. Sometimes the purchase of land was made earlier for investment purposes. At a time when land prices were rising rapidly, the land plot became a financial investment as the property was to be sold at a profit in the future. The economic slowdown and the subsequent inhibition of property price growth made the sale of the land plot less profitable, and the decision was made to change the business concept, resulting in the construction of a hotel on the plot. In one case the land plot was purchased by a business company. The purpose of the purchase was to construct an office building for rent. In the meantime, however, one of the partners had withdrawn from the company and it was not possible to carry out the existing investment projects due to capital shortages. Therefore, the decision was taken to alter the planned business activity and open a small hotel instead of the previously planned office building. The study also included a situation where the owner previously owned a plot of land inherited from his parents, and his decision to build a hotel was based on its attractive location.

The second pathway was taken by $24 \%$ of hotels where the choice of location was connected with the analysis of subjective factors. This process was associated with the need to find a suitable plot of land and create a functional concept for the hotel. However, the actions taken by the decision-makers were not fully rational as they were based on subjective premises, i.e. behavioral factors. The choice of locations in which hotels were later built was determined either by the decision-maker's place of origin or residence, intuition, spontaneous decision, or an opportunity to purchase a plot of land in an attractive place and at an attractive price.

One of the decision-makers declared that he opened the new hotel at his children's insistence. He was considering a land plot originally intended for other purposes, but under the influence of his children he decided to change his business concept. An interesting case was a situation where the owner somehow combined the two described pathways and, when choosing a secondary location for her hotel was guided mainly by behavioral factors. Previously, she had run a small hotel in another location, but it did not fully meet demand. The lack of a reserve location, resulting from the existence of close development around the facility, made it impossible to expand. The owner, guided by her sentiment towards the place where she had run her business so far, purchased a large building in the vicinity of a former cinema and opened a new hotel there. The old property was leased to another business for non-tourist purposes.

The third pathway, indicated by $40 \%$ of decisionmakers, included a rational choice of primary location taking into account such factors as demand flow, transport accessibility, proximity to a communication hub, tourism assets (natural and cultural), central location, limited competition and low land prices. These entrepreneurs considered at least two alternative locations for their hotels, but their thorough analysis did not ensure their complete satisfaction with the location. The uncertainty led them to use three behavioral premises. 


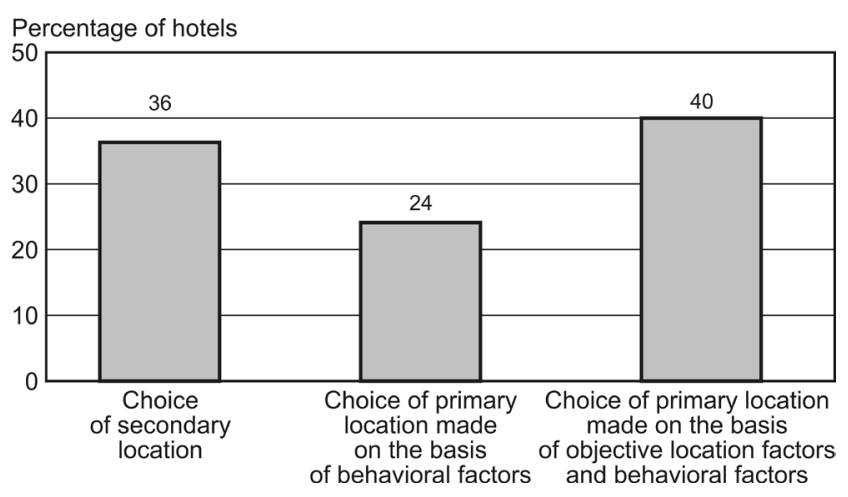

Figure 2. Choice pathways for the location of hotels in Opolskie Province based on subjective factors Source: author on the basis of survey results

Most of them declared that they relied on their intuition in choosing the location of the hotel. Sometimes other entrepreneurs were emulated and a new hotel was opened in towns where prosperous facilities of this kind were already operating. In one case, the main factor was the decision-maker's past experience. Previously, he had run a restaurant in another place, which he had chosen independently, therefore in this case he made an independent choice based on his own conviction that a hotel located here would have a greater chance of business success (Fig. 2).

\section{CONCLUSION}

The results of the study confirm the importance of behavioral factors in the process of selecting the location of independent hotels in Opolskie Province. This selection was connected with both secondary and primary locations. In the latter case the decision-making process was based entirely on behavioral factors or complemented them when the objective approach resulted in a lack of decision-making certainty. In this case, therefore, behavioral factors were of key importance in determining the final choice of hotel location.

An important strength of the research is its innovative subject matter since the significance of behavioral factors of hotel location had not been examined empirically before. A weakness is the limited spatial scope and the use of qualitative methods only.

In the author's opinion, several points should become subjects for further reflection:

1. The spatial scope of research covering Opolskie Province allows certain assumptions to be made concerning the entire hotel market. In order to examine these assumptions, it is necessary to carry out comprehensive research covering the whole of Poland or even Central and Eastern Europe.

2. To increase the reliability of the research results the principles of 'triangulation' should be applied in subsequent studies. Triangulation should involve data from various sources, a combination of quantitative and qualitative methods and techniques, data analysis using several statistical techniques and environmental analysis (location of hotels in different countries and regions).

3. The review and critical analysis of the literature indicates a lack of a comprehensive research on the issue of hotel location in both its general (country, region, municipality) and specific aspects (land plot).

4. Research on location factors of tourism enterprises other than hotels should also be considered important, with a particular emphasis on other hospitality entities, travel agencies, tourism attractions, recreation centers, etc.

\section{REFERENCES}

Albert Tóth, A., Rechnitzer, J. (2018). Choice of location in the hotel industry. Tér és Társadalom, 32 (3), 128-142. DOI: https:// doi.org/10.17649/TET.32.3.3054

Alexander, N., Lockwood, A. (1996). Internationalization: A comparison of the hotel and retail sectors. The Service Industries Journal, 16 (4), 458-473. DOI: https://doi.org/10.1080/02642069600000041

Budner, W. (2004). Lokalizacja przedsiębiorstw. Aspekty ekonomiczne, przestrzenne i środowiskowe. Poznań: Wydawnictwo Akademii Ekonomicznej w Poznaniu.

Butler, R. (1980). The concept of a tourist area cycle of evolution: Implications for management of resources. The Canadian Geographer, 24 (1), 5-12. DOI: https://doi. org/10.1111/j.1541-0064.1980.tb00970.x

Cheng, S. (2018). Autocratic multi attribute group decision making for hotel location selection based on interval-valued intuitionistic fuzzy sets. Information Sciences, 427, 77-87. DOI: https://doi.org/10.1016/j.ins.2017.10.018

Chou, T., Hsu, C., Chen, M. (2008). A fuzzy multi-criteria decision model for international tourist hotel's location selection. International Journal of Hospitality Management, 27 (2), 293-301. DOI: https://doi.org/10.1016/j.ijhm.2007.07.029

Christaller, W. (1964). Some considerations of tourism location in Europe: The peripheral regions underdeveloped countries - recreations areas. Papers, Regional Science Association, 12 (2), 95-105. DOI: https://doi.org/10.1007/BF01941243

Damborsky, M., Wokoun, R. (2010). Location factors of small and medium entrepreneurship under the economic conditions of the Czech Republic. E\&M Ekonomie a Management, 13 (2), 32-43.

Główny Urząd Statystyczny (2019). Retrieved from: www.stat. gov.pl (7.06.2019).

Godlewska, H. (2005). Lokalizacja działalności gospodarczej. Warszawa: Wyższa Szkoła Menedżerska w Warszawie.

Griffin, D., Tversky, A. (1992). The weighing of evidence and the determinants of confidence. Cognitive Psychology, 24 (3), 411-435. DOI: https://doi.org/10.1016/0010-0285(92)90013-R

Hotelling, H. (1929). Stability in competition. Economic Journal, 39 (1), 41-57. DOI: https://doi.org/10.2307/2224214

Ju, P., Zhang, H., Wang, J. (2018). A projection-based outranking method with multi-hesitant fuzzy linguistic term sets for hotel location selection. Cognitive Computation, 10, 737-751. DOI: https://doi.org/10.1007/s12559-018-9552-2

Kahneman, D. (2011). Pułapki myślenia. O myśleniu szybkim i wolnym. Warszawa: Media Rodzina. 
Kowalczyk, A. (2001). Geografia hotelarstwa. Łódź: Wydawnictwo Uniwersytetu Łódzkiego.

Kuciński, K. (2009). Geografia ekonomiczna. Kraków: Oficyna Wolters Kluwer Business.

Kundu, S., Contractor, F. (1999). Country location choices of service multinationals: An empirical study of the international hotel sector. Journal of International Management, 4, 299-317. DOI: https://doi.org/10.1016/S1075-4253(99)00017-4

Leśniewska-Napierała, K., Napierała, T. (2017). Funkcja hotelarska w rewitalizacji obszarów wiejskich. Studium przypadków w województwie pomorskim. Turyzm/Tourism, 27 (2), 65-76. DOI: https://doi.org/10.18778/0867-5856.27.2.06

Mariotti, S., Mutinelli, M., Piscitello, L. (2008). The internationalization of production by Italian industrial districts' firms: Structural and behavioural determinants. Regional Studies, 42 (5), 719-735. DOI: https://doi.org/10.1080/00343400701543264

Matczak, A. (2017). Zmiany w liczbie i pojemności hoteli w Polsce. Turyzm/Tourism, 27 (2), 77-87. DOI: https://doi. org/10.18778/0867-5856.27.2.07

Ministerstwo Sportu i Turystyki (2019). Retrieved from: www. msit.gov.pl (12.06.2019).

Miossec, J. (1977). Un modele de lespace touristique. L'Espace Géographique, 6 (1), 41-48. DOI: https://doi.org/10.3406/ spgeo.1977.1690

Popovic, G., Stanujkic, D., Brzakovic, M., Karabasevic, D. (2019). A multiple-criteria decision-making model for the selection of a hotel location. Land Use Policy, 84, 49-58. DOI: https://doi. org/10.1016/j.landusepol.2019.03.001

Puciato, D. (2015). Przestanki lokalizacji hoteli w Polsce. PhD thesis. Warszawa: SGH.

Puciato, D. (2016). Attractiveness of municipalities in SouthWestern Poland as determinants for hotel chain investments. Tourism Management, 57, 245-255, DOI: https://doi.org/ 10.1016/j.tourman.2016.06.019

Puciato, D., Dziedzic, E. (2017). The attractiveness of the municipalities of the south-western Polish for hotel investors. Tourism Economics, 23 (3), 702-711. DOI: https://doi.org/ 10.5367/te.2016.0539

Puciato, D., Gawlik, A., Goranczewski, B. (2016). The origin of capital as a factor influencing location of new hotels on the example of Poland. International Journal of Contemporary Management, 15 (4), 31-55. DOI: https://doi.org/10.4467/2449 8939IJCM.16.023.6704

Puciato, D., Gawlik, A., Goranczewski, B., Oleśniewicz, P., Woś, B., Jandová, S., Markiewicz-Patkowska, J., Sołtysik, M. (2017). The factors influencing the decision on the location of hotels depending on their size in Poland. EEM Ekonomie a Management, 20 (2), 216-225. DOI: https://doi.org/10.15240/tul/001/2017-2-016
Puciato, D., Oleśniewicz, P., Gawlik, A., Markiewicz-Patkowska, J., Widawski, K., Słaby, T., Kasprzak, R., Mróz-Gorgoń, B. (2019). Location factors for budget, medium standard and luxury hotels based on the example of hotels operating in Poland. Operation Research and Decisions, 29 (1), 61-73. DOI: https://doi. org/10.5277/ord190104

Ren, L., Qiu, H., Ma, C., Lin, P. (2018). Investigating accommodation experience in budget hotels. International Journal of Contemporary Hospitality Management, 30 (7), 2662-2679. DOI: https://doi.org/10.1108/IJCHM-11-2016-0625

Romero-Martinez, A., Garcia-Muina, F., Chidlow, A., Larimo, J. (2019). Formal and informal institutional differences between home and host country and location choice: Evidence from the Spanish Hotel Industry. Management International Review, 59 (1), 41-65. DOI: https://doi.org/10.1007/ s11575-018-0369-8

Thaler, R., Sunstein, C. (2017). Impuls. Jak podejmować właściwe decyzje dotyczace zdrowia, dobrobytu i szczęścia. Warszawa: Wydawnictwo Zysk i Spółka.

Townroe, P. (1972). Some behavioural considerations in the industrial location decision. Regional Studies, 6 (3), 261-272. DOI: https://doi.org/10.1080/09595237200185221

Ussi, M., Wei, J. (2011). The location determinants for hotel foreign direct investment in Zanzibar. Management and Service Science, 8, 105-112.

Włodarczyk, B. (2017). Hotele w przestrzeni miejskiej Łodzi. Turyzm/Tourism, 25 (2), 63-76.

Yang, Y., Wong, K., Wang, T. (2012). How do hotels choose their location? Evidence from hotels Beijing. International Journal of Hospitality Management, 31 (3), 675-685. DOI: https://doi. org/10.1016/j.ijhm.2011.09.003

Zhank, H., Guillet, B., Gao, W. (2012). What determines multinational hotel groups' locational investment choice in China. Hospitality Management, 31 (2), 350-359. DOI: https://doi. org/10.1016/j.ijhm.2011.05.008

Zielonka, P. (2011). Giełda i psychologia. Behawioralne aspekty inwestowania na rynku papierów wartościowych. Warszawa: CeDeWu.

Żakowska, S., Podhorodecka, K. (2018). Rozmieszczenie walorów turystycznych a lokalizacja noclegowej bazy turystycznej w województwie łódzkim. Turyzm/Tourism, 28 (2), 79-91, DOI: https://doi.org/10.18778/0867-5856.28.2.09

Article received:

15 August 2019

Accepted:

18 June 2020 